\section{Brazilian Secrets Hair Case}

O Caso da Empresa Brazilian Secrets Hair

\section{Lucyana Felicia $^{10}$ \\ Clarice Secches Kogut ${ }^{10}$ \\ Renato Dourado Cotta de Mello ${ }^{10}$}

\section{INTRODUCTION}

Andréa Vieira is the founder and CEO of the company Brazilian Secrets Hair, a global company specialized, as the name says, in hair products and born, as the name says, in Brazil.

As Andréa drives home from work on a street of Rio de Janeiro, she cannot forget a conversation she had earlier that day, during a doctor's appointment:

"So, tell me, Ms. Andréa, what do you do for living?" asked the doctor, a very well-dressed woman with an apparently curly but straightened hair.

"I own a company called Brazilian Secrets Hair, specialized in hair straightener products", answered Andréa.

"Oh, that's very nice, but I don't think I have ever heard of this company... Where do you sell your products?"
"We don't actively sell in Brazil, only abroad; we export to over 20 countries", replied Andréa, already expecting what was about to come, as she had had this type of conversation more than a dozen times over the last years.

"Really? How come? I have never heard of a company that goes global and is not present in its home country! How is it possible? Why don't you sell it in Brazil? I bet you would have a huge market here!"

The doctor was right; Brazil was a huge market. Should Andréa reconsider her original position and actively prospect the domestic market? What are the pros and cons of such change? What should be BSH's expansion strategy for the future? For the first time in years, that conversation influenced her, as she had heard an international partner was interested in investing in the Brazilian market. So, she scheduled a meeting with the company's administrative supervisor Karen Felismino to discuss it.

JEL Code: A2, F2, L6.

${ }^{1}$ Universidade Federal do Rio de Janeiro, Instituto de Pós-Graduação e Pesquisa em Administração (COPPEAD), Rio de Janeiro, RJ, Brazil.

Cite as: Felicia, L., Kogut, C. S., \& Mello, R. D. C. de. (2020). Brazilian secrets hair case. Revista de Administração Contemporânea, 24(5), 474-486. https://doi.org/10.1590/1982-7849rac2020180076
Editor-in-chief: Wesley Mendes-Da-Silva (Fundação Getulio Vargas, EAESP, Brazil) la C. P. de S. Chimenti (Universidade Federal do Rio de Janeiro, COPPEAD, Brazil) Reviewers: Ilan Avrichir (Escola Superior de Propaganda e Marketing, Brazil) Anete Alberton (Universidade do Vale do Itaiaí, PPGA, Brazil) Daniela Abrantes Ferreira (Universidade Federal do Rio de Janeiro, Brazil) (c)

\begin{tabular}{|c|c|c|c|c|c|c|c|c|c|}
\hline & 1 & 2 & 3 & 4 & 5 & 6 & 7 & 8 & 9 \\
\hline $1^{\text {st }}$ round & קִ & 9 & & & & & & & \\
\hline $2^{\text {nd }}$ round & 9 & 2 & & & & & & & \\
\hline $3^{\text {rd }}$ round & 2 & x & 2 & & & & & & \\
\hline $4^{\text {th }}$ round & 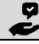 & & & & & & & & \\
\hline
\end{tabular}




\section{THE ENTREPRENEUR'S BACKGROUND}

In 2004, Andréa Vieira had her first entrepreneurial experience, having started Inovagine, one of the first companies in Brazil to market feminine soaps for intimate cleaning and for underwear washing. However, after operating in a domestic environment with many barriers and having no commercial strength to enter large sales points, she ended up having to sell the formula of her products to a competitor and seek a new venture.

Based on that first frustrated attempt, Andréa decided that in her next entrepreneurial business, the international market would be her target; she would continue working in the cosmetics, toiletries and fragrances (CT\&F) industry, but with a new product.

Andréa, with a bachelor's degree in Economics and an MBA in Marketing from a French University, already had eight years of professional experience in companies in the CT\&F industry and used her accumulated knowledge and experience abroad to develop a new brand.

\section{THE COSMETICS, TOILETRIES AND FRAGRANCES (CT\&F) INDUSTRY}

The CT\&F industry has worldwide revenues of about US\$ 465 billion. The world's fastest growing sales category is skin care, followed by hair care, which includes BSH's main products. The companies with the largest share in the global CT\&F market focus not only on the mass market, such as P\&G and Unilever (market leader and third place, respectively), but also on the production of more sophisticated products, such as L'Óreal (second place), adding some differentiation and innovation.

The Brazilian market, with approximately US\$ 14.5 billion worth of annual revenues, accounts for about $6.9 \%$ of the global industry, being the fourth largest consumer market in CT\&F (third in hair products). The target market for Brazilian exports is basically the Latin American territory, and exported products are mainly related to hair and oral care. While the CT\&F industry is highly significant for the Brazilian economy and presented an annual compounded growth of $8.2 \%$ over the last 10 years, it is highly concentrated: as few as 20 of the $+2,500$ companies operating in this segment account for $73 \%$ of industry revenues, and the five largest players (Natura, Unilever, $\mathrm{O}$ Boticário, P\&G, and Avon) generate 50\% of total revenues.

It may be noted that the CT\&F industry is considered strategic by the Federal Government, in view of the importance given to Beautycare Brazil, the industry-specific project developed by Apex (the Brazilian government export fomenting agency) in tandem with
ABIHPEC (Associação Brasileira da Indústria de Higiene Pessoal, Perfumaria e Cosméticos), the CT\&F industry's national association. This initiative, of which Brazilian Secrets Hair is a part, started in the year 2000 and focuses mainly on training and coaching Brazilian companies that seek to expand internationally, as well as on assisting those that already operate as export traders. Its mission is "to be nationally and internationally recognized as the most important support platform for the internationalization of the CT\&F production chain, technically enabling companies, facilitating business generation and strengthening the image of excellence in innovation, technology and sustainability in Brazil". From a practical perspective, the project coordinates the participation of Brazilian companies in international fairs, business roundtables, prospecting initiatives, consumer market research, etc., facilitating and speeding the companies' expansion to international markets by connecting them to potential international clients and partners. In addition, it provides all the necessary support on regulatory and technical issues (especially health and safety rules, which vary from one country to another), offering guides and manuals to participating companies. The project also influences the companies' selection of target markets. The purpose of the Beautycare Brazil industry-specific project is to establish business relations with Angola, the United States, Colombia, Peru, the United Arab Emirates, Portugal, Mexico, Chile, South Korea, Germany, and France. This selection of target markets is based on the import potential of the countries as an economic variable.

\section{BRAZILIAN SECRETS HAIR}

\section{Company's background}

Being familiar with the CT\&F industry and aware of the significant recognition of the 'Brazilian brand' by the specific segment of toiletry and hair treatment abroad due to her previous experiences, Andréa decided to start a company named Brazilian Secrets Hair (BSH) in 2010.

Karen Felismino witnessed the beginning of the new products' development, and recalls that "Brazilian keratin was on the rise, so the firm took advantage of the fact that foreign consumers appreciated Brazilian natural products as well as health and wellness products, and designed a hair straightening product that did not use formalin in its formula."

The benefit of the so-called 'made in' effect has been an important issue for Andréa from the outset, as she believes it raises the perception of product quality. For her, being associated with Brazil in the cosmetics segment is an 
advantage, since the country has become a benchmark in this regard.

Other aspects considered extremely important to Andréa were innovation and product development. She considered research and development of new products in other companies were very poorly explored-allowing her to succeed in creating a truly innovative product in the segment. Therefore, one of its first and most important employees of the company was a chemist, specialized in hair products. His role was to develop exclusive products that associated the aforementioned characteristics: use of ingredients that refer to Brazil as the country of origin, and innovation.

Production was not a main concern for Andréa, so she chose not to be the direct manufacturer of the items the company sells, nor to have its own manufacturing facilities.

\section{The company's internationalization process}

From the outset, due to her first entrepreneurial experience, Andréa has targeted the international market. She implemented a 'backward process' of product development, as she put it: first, she analyzed which countries had the strictest regulatory environment, kept abreast of all the obligations involved in these jurisdictions, and then developed her product from inception seeking to respect the stricter limitations on components in the formulas. According to her, some raw materials used in Brazilian products are not accepted in certain countries, and if she really wanted the world as her target market, it would be necessary to develop a product that could be marketed in as many places as possible.

Another important decision Andréa made when BSH started was to join ABIHPEC and to take part in Beautycare Brazil, the industry-specific project developed in partnership with Apex. According to Karen Felismino, to target the international markets, membership of this program was essential; and due to its investments in innovation, from the outset the company has been categorized as a 'top-tier company' in ABIHPEC's rating (companies of the program are audited and graded).

Through this association, BSH started participating not only in international fairs, but also in roadshows and international business rounds. Participations were financially supported by ABIHPEC, which, besides subsidizing a large part of the costs involved, was responsible for organizing business missions with entities like consulates, embassies, and others. These initiatives have enabled BSH to target the international markets faster, with fewer resources (both financial and operational) and with a lower level of risk/uncertainty. Andréa believes this support was crucial for her firm's internationalization, having provided not only the financial resources but also market knowledge and the mapping of opportunities.

She knew that relationships would only emerge as the brand became known internationally and taking part in these events could serve as a showcase for the firm in terms of brand building. Moreover, as these fairs introduce the major global trends in each industry, even if $\mathrm{BSH}$ were only considering potential markets, its involvement would be vital to live up to the innovation standards, as previously mentioned.

Although the first markets considered were in Asia, namely Japan and Korea (where the regulatory environment is stricter), the first country to which Andréa exported her product in 2010 was France, one she was already familiar with (where she had done her MBA).

The firm initially used a trading company as an intermediary to facilitate its entry. The firm then decided to directly explore this market and hired an exclusive agent to operate in the country, which was decisive in expanding the brand to other French-speaking territories. Karen defends the strategy by saying that "in order to start exporting somehow, we thought it would be better to use a trading company due to our lack of experience. Once the company specialized, we started exporting directly."

After entering France, the company's active participation in fairs and events promoted by Beautycare Brazil in target countries (defined by the program and agencies) resulted in intense international expansion, to the point that Andréa "could not precisely say which country was next" . But actual market entrance occurred at a different speed in each country, given the regulatory limitations and the very difficulties that can be posed by each market. Andréa further asserts that prospecting several markets at the same time was what made her export strategy work, gaining in sales volume and brand awareness, without losing the timing. This was only possible with the support of Apex and ABIHPEC through the Beautycare Brazil program, which would define and study target markets for the sector as a whole and organize business interactions for the companies to meet potential partners. Despite the risk of this accelerated backed-up entry strategy, Andréa explains that an additional confirmatory feasibility study for each market would be conducted after a distributor showed interest in selling her products in a new market, with variables such as population characteristics, infrastructure, and culture being considered. She mentions Peru as a rare example in which the company decided not to enter a market indicated by the program: as many women already have straight hair, potential demand would not be enough to make up for the cost of investing in that market. But in general, BSH 
would follow the program's recommendations and trust their selection.

In the years that followed, the firm also entered other French-speaking countries-using the same exclusive agent that worked in the development of the French market-in other regions of Europe and in North Africa.

In 2012, after having attended fairs held in Dubai, the firm entered Saudi Arabia, and several other Arab countries in the years that followed, supported by the local partner Nazih, a large distributor group.

It was during the Middle East expansion that the firm recognized the importance of the cultural differences when entering a new market, as this could limit the product acceptance in the country or require changes in formulas and packaging. The firm expanded into that region after having attended the Beautyworld Middle East fair, held annually in Dubai. Andréa noted that markets like the United States and Europe were less heated up and that the number of participants in the fair had grown by $1000 \%$ in four years, so BSH's participation was worth it. In addition, there was the issue of city centricity, given that "Dubai became fashionable, ... but also became a re-export hub" to countries in the region.

Starting in 2014, the firm continued to close sales deals in Latin America and Eastern and Northern Europe, including Poland (2015).

\section{The company's strategy}

The company was already present in over 20 international markets. In the Americas, BSH was only in Panama. As mentioned, its home country, Brazil, was not actively exploited commercially, only hosting the company's headquarters. Operations in Africa included Morocco, Algeria, Tunisia, and Egypt. In the European continent, it had already expanded over France, Italy, Portugal, Belgium, Poland, Romania, Malta, and Switzerland. In Asia, supported by the Nazih Group operations, it was present in Dubai, Saudi Arabia, Kuwait, Bahrain, Qatar, and Jordan. Finally, in Oceania the firm was in the Australian market. In order to sustain its local presence in all these countries, the firm had its own structure located in the city of Rio de Janeiro, with only eight employees, all directly involved in the internationalization process and reporting to Andréa.

The Nazih Group was also very important for the firm's international expansion. Operating only in the Middle Eastern market, the distributor established a training center in partnership with BSH in Dubai and had recently visited Brazil in order to check the local market for potential exploration in the future.
The internal projects were designed by Andréa herself, who continually monitored trends in the global market, and by the firm's chemist, who developed the formulas to be used. The goal was to create hair products as natural as possible, using Brazilian biodiversity, especially from the Amazon. Andréa focused on the development of hair straightening products, but she was open to new ideas.

The firm marketed four brands: BSH Pro Keratin, X-Liso, Hair.Toxx and Argila Amazônia. Although some of these products have virtually the same formula, creating different brands has been the strategy adopted to expand the firm's share in foreign markets under exclusivity arrangements with more than one distributor per region.

The decision to focus primarily on brands for professionals in the beauty industry - rather than the final customer - was explained by the higher margins. However, these products also required differentiated training services offered by BSH and exclusive territory arrangements. Of the brands mentioned, X-Liso was the only one that was not developed for sale to beauty professionals from start. Its application was easier so that the end customer could purchase the product in drugstores and beauty supply stores and handle it at home, without professional help. However, according to Andréa, X-Liso also served to enter markets that experienced a more sensitive economic situation, resulting in X-Liso winning a large market share and being the second best-selling product in BSH's sales ranking.

\section{NEXT STEPS}

When asked about BSH's next steps, Andréa would answer she will continue to focus in the international market, not being interested in winning the domestic market.

But is this the best strategy for BSH? Andréa struggles with several doubts as she plans the next steps of the company: is it possible for a company to be globally competitive if not competitive, or at least present, in its domestic market? And even worse, is it credible for a company that has its country of origin in the brand name not to be present domestically?

As for the international expansion, future is not clear either: should Andréa aim at winning new markets or expand the firm's presence abroad from a qualitative perspective, by adding value to the brand in the countries where it already operates?

All these doubts prompted Andréa to schedule a meeting with Karen Felismino to plan the years ahead and discuss "what should be BSH expansion strategy?". 


\section{Teaching Notes}

\section{ABSTRACT}

This is a case for teaching focused on the internationalization process of Brazilian Secrets Hair (BSH), a company that has considered the world as its target market since its start, and is part of an ever-growing segment: the cosmetics industry. Upon understanding the company's international expansion, the internationalization theories within the behavioral approach, such as the Uppsala theory, the network theory, the entrepreneurship perspective, and the effectuation logic, can be explored, answering questions related to market selection processes, entry mode choices, and global expansion strategy decisions. This case was based on primary and secondary data from a real company and was originally designed for international business classes of graduate courses.

Keywords: international entrepreneurship; internationalization of firms; cosmetics industry; internationalization behavioral theories; teaching case.

\section{CASE SYNOPSIS}

This case is about a Brazilian company in the cosmetics, toiletries and fragrances (CT\&F) industry, namely Brazilian Secrets Hair (BSH). The company was founded in 2010 with the world as its target market and, having no active presence in the Brazilian domestic market, by the end of 2016 the firm was already present in over 20 countries abroad.

Operating with only eight employees, no production facilities of her own and no presence in the domestic market, the entrepreneur Andréa Vieira is now questioning herself about some of her decisions: has BSH grown too fast and should slow down to consolidate the markets it is already in? Should it benefit from the good momentum of the company and the industry and keep growing? Should it enter its domestic market, Brazil? What are the pros and cons of each option?

Is it possible for a company to be globally competitive if not competitive, or at least present, in its domestic market? And even worse, is it credible for a company that has its country of origin in the brand name not to be present domestically?

\section{RESUMO}

Este é um caso para ensino focado no processo de internacionalização da Brazilian Secrets Hair (BSH), uma empresa que considerou o mundo como seu mercado-alvo desde a sua fundação, e faz parte de um segmento crescente: a indústria de cosméticos. Para analisar a expansão internacional da empresa, as teorias de internacionalização dentro da abordagem comportamental, tais como a teoria de Uppsala, a teoria de redes, a perspectiva de empreendedorismo e a lógica de Effectuation são exploradas, respondendo questões relacionadas a processos de seleção de mercado, opções de modo de entrada e estratégias de expansão. Este caso foi baseado em dados primários e secundários de uma empresa real, e foi originalmente projetado para disciplinas de negócios internacionais em cursos de MBA/ pós-graduação.

Palavras-chave: empreendedorismo internacional; internacionalização de empresas; indústria de cosméticos; teorias comportamentais de internacionalização; caso de ensino.

All things considered, Andréa needs to reflect and decide on what should be BSH's expansion strategy for the future.

\section{PURPOSE OF THE CASE}

The purpose of this teaching case is that, as in other teaching cases, the student puts himself in the shoes of the protagonist of the case, reflecting and ultimately making decisions on the specific questions proposed.

The primary objective of this case is giving students the opportunity to learn important theories of internationalization through a real case. As such, it is important to study how the firm has internationalized: how did it enter the foreign markets (entry modes), how did it choose the countries to enter (market choices), and the factors (entrepreneur's decision logic) and players (networks) that somehow influenced its entrance and expansion into the international market. It is expected that, at the end of the session, students have arrived inductively at the following concepts and theories (educational objective). 
Table 1. Internationalization theories and concepts to be learned with the case.

\begin{tabular}{|c|c|c|}
\hline Internationalization theories & Key variables & Authors \\
\hline $\begin{array}{l}\text { Gradual internationalization } \\
\text { (Uppsala model) }\end{array}$ & $\begin{array}{l}\text { - Entry modes into international markets } \\
\text { - First foreign market } \\
\text { - Sequence of international expansion } \\
\text { - Significance of individuals } \\
\text { - Pace of international expansion }\end{array}$ & $\begin{array}{l}\text { Johanson and Vahlne }(1977 ; 1990 ; 2009) \\
\text { Vahlne and Johanson }(2013) \\
\text { Vahlne and Johanson }(2017)\end{array}$ \\
\hline Networks & $\begin{array}{l}\text { - Previous (social and/or business) relationships } \\
\text { - Existing (formal and/or informal) partnerships } \\
\text { abroad } \\
\text { - Role of networks in a firm's international } \\
\text { expansion } \\
\text { - Firm's position within networks }\end{array}$ & $\begin{array}{l}\text { Johanson and Mattson (1988) } \\
\text { Johanson and Vahlne (2009) } \\
\text { Chetty and Agndal (2007) } \\
\text { Chetty and Stangl (2010) } \\
\text { Schweizer (2013) } \\
\text { Oparaocha (2015) }\end{array}$ \\
\hline $\begin{array}{l}\text { International } \\
\text { entrepreneurship }\end{array}$ & $\begin{array}{l}\text { - Venture creation process } \\
\text { - Search for international market } \\
\text { - Selection of foreign market } \\
\text { - Period between venture creation and completion of } \\
\text { first business deal abroad } \\
\text { - Governance structure adopted } \\
\text { - Focus on domestic/international market }\end{array}$ & $\begin{array}{l}\text { Oviatt and McDougall (2005) } \\
\text { Coviello, McDougall, and Oviatt (2011) } \\
\text { Jones, Coviello, and Tang (2011) } \\
\text { Gabrielson and Kirpalani (2004) } \\
\text { Rennie (1993) } \\
\text { Autio (2005) }\end{array}$ \\
\hline Effectuation & $\begin{array}{l}\text { - Entrepreneurial profile } \\
\text { - Decision-making logic } \\
\text { - Entrepreneur's vision of the future } \\
\text { - Positioning regarding risk vs. opportunity } \\
\text { - Company's adaptability to each market }\end{array}$ & $\begin{array}{l}\text { Andersson (2011) } \\
\text { Galkina and Chetty (2012) } \\
\text { Sarasvathy (2001) } \\
\text { Sarasvathy, Kumar, York, and Bhagavatula } \\
\text { (2014) }\end{array}$ \\
\hline
\end{tabular}

Note. Source: Prepared by the authors.

\section{TARGET AUDIENCE}

This case was designed for graduate students, both stricto and lato sensu, ideally in disciplines related to International Business and global strategies. With some adaptations, it can also be used in International Marketing courses, exploring the company's name choice and concepts of provenance paradox, country of origin, and 'made in' effect (please refer to some references at the end of this document).

\section{SOURCES OF INFORMATION}

This teaching case was anchored in research derived from both primary and secondary data. For the collection of primary data, in-depth interviews were held with the company's founder and current CEO Andréa Vieira, and with the assistant director Karen Felismino. Data was then triangulated, reconciled, and organized (Eisenhardt, 1989) to compose the case as presented. Both company's and characters' names used are real.

\section{SUGGESTED TEACHING PLAN}

\section{Assignment questions}

- Why did BSH choose to expand internationally before operating in the domestic market? Considering BSH's long-term strategy, do you think it can continue to succeed globally having no presence in its domestic market?

- What was BSH's entry mode? Why do you think that was? Has it changed over time? Can you think of possible entry modes for a company planning to start operating in a new country?

- How was the process of market selection at BSH? Did anyone influence the firm's expansion? Can you think of other possible ways of selecting new markets? Why do you think Andréa opted for one process instead of the other? Would you enter the Brazilian market if you were Andréa? Why? What should be considered in making this decision (pros and cons of entering)? 
It is worth noting that there is no financial data available in the case as the company opted not to disclose them. For the assignment questions, instructors should ask students to base their discussions in strategic arguments and qualitative information present in the case (no need for financial calculations). As this teaching case was designed for international business classes, we believe financial calculations are not necessary at this point to discuss and arrive at main IB theories. If the instructor still wants to take the discussion further, he or she can ask students to make financial assumptions to base their arguments.

\section{Discussion plan and analysis}

This teaching plan assumes previous case reading and preparation by students and a session of two hours length. Suggestion of class time allocation is as follows:

- Beginning of session and division of class in small groups of 4 or 5 students ( 5 minutes);

- Discussion of assignment questions in small groups (25 minutes);

- Case introduction (15 minutes);

- Analysis of the case (about 60 minutes). Instructor can choose to go through all points of analysis or just a few;

- Closure (about 15 minutes).

\section{Introduction}

To begin the class, the instructor can do, or ask a student to do, a brief recap on dates and events of the case, as per Table 2 below. This will serve as a warm-up for the class.

Table 2. Main dates and events of the case.

\begin{tabular}{cl}
\hline Dates & \multicolumn{1}{c}{ Events } \\
\hline 2004 & Entrepreneur's first business attempt-Inovagine \\
2010 & Creation of Brazilian Secrets Hair (BSH) \\
2010 & Exports to France begin \\
2011 & Exports to other francophone countries begin \\
2012 & Exports to Middle East begin \\
2014 & $\begin{array}{l}\text { Exports to Latin America and Northern and Western } \\
\text { Europe begin }\end{array}$ \\
\hline 2016 & $\begin{array}{l}\text { BSH is present in 20 countries abroad, still not } \\
\text { actively present in Brazil }\end{array}$ \\
\hline
\end{tabular}

As the instructor goes over the events, he (or she) can ask relevant questions about the case and that lead to the next event, such as:

- 2004: What went wrong with Inovagine?

- 2010: Creation of Brazilian Secrets Hair (BSH). Instructor can prompt students to expand a little on characteristics of the company.

\section{Analysis}

Linking the warm-up with the first part of the analysis section of the case, the instructor can ask the class how many students have heard of the Brazilians Secrets Hair company and how many have actually tried the product. For those who have tried, instructor should ask about their experience with the product and the brand.

As a new and still small company, it is expected that very few, if any, students know the brand, even if, or especially if, the class is being taught in its home country, Brazil. The instructor should emphasize this fact and point out that the brand is not present in its own domestic market, introducing the first question for analysis:

- Why did BSH choose to expand internationally before operating in the domestic market? Is this a common path followed by companies in their internationalization processes?

Students are expected to give answers related to the case (bad experience with Inovagine, difficulties encountered in the Brazilian domestic market, larger market, etc.) and the instructor should help them build the concepts of international new ventures (INV) and born globals (BG) inductively.

The terms 'international new ventures' and 'born globals' may even be used interchangeably (Coviello, McDougall, \& Oviatt, 2011). They introduce a new perspective into the internationalization process of firms, analyzing the specificities of companies that internationalize practically upon inception.

Born globals were defined by Rennie (1993) as a new category of companies that are different from traditional organizations in terms of entering the international market. Traditional firms are consolidated organizations that have international operations, but, even so, focus their activities in the domestic market. Born globals, on the other hand, are small and medium enterprises (SMEs) that start operating in the international market shortly after their inception and prioritize these international operations. Oviatt and 
McDougall define an INV as “... a business organization that, from inception, seeks to derive significant competitive advantage from the use of resources and the sale of products in multiple countries (Oviatt \& McDougall, 2005, p. 31).

With no presence in the domestic market and implementing a rapid international expansion, BSH can definitely be considered a born global.

- Considering BSH's long-term strategy, do you think it can continue to succeed globally having no presence in its domestic market?

According to Rennie (1993) and to Oviatt and McDougall (2005), some factors allowed newly founded firms to expand internationally, without having to go through the maturity phase in the domestic market. These factors included technological innovations, the possibility of acquiring knowledge from the foreign market, and the use of alternative corporate governance structures. But, more importantly, the international transaction costs decreased with technological development, lowering communication and freight costs, and allowing newly founded firms such as BSH to compete with large multinationals. Related to this, there is also the globalization phenomenon, which favored the homogenization of international markets, shortening psychic distances and "promoting the integration of markets" (Autio, 2005, p. 11).

Thus, as long as the INVs have unique and valuable resources that ensure them a sustainable competitive advantage, they will be able to compete in the international scenario from inception without the need to have a previously established large-sized business (Oviatt \& McDougall, 2005). BSH's CEO, Andréa, believes that its unique and valuable resources are its innovation capacity and 'Brazilianess', attested by both the ingredients used in the formula and the country of origin of the brand - the so-called 'made in' effect (please refer to additional references at the end of the document).
Moreover, Rennie (1993) believes that born globals are able to compete in the international arena with multinational corporations also because of a change in consumer behavior itself, as a new emerging class of consumer demands more customized products, thus increasing the focus on niche markets and consequently smaller-scale businesses. One of BSH's attributes that contributed to its accelerated internationalization activities refers to the marketed product: a customized and specific good designed for a niche consumer group. Andréa considers that her product's value added, which allows the firm to yield higher profit margins, enabled its international expansion, since BSH would not have the financial capacity to start these internationalization efforts while producing in a large scale.

- Can you think of possible entry modes for a company planning to start operating in a new country? What was BSH's entry mode? Why do you think that was? Has it changed over time?

The instructor should use this assignment question to review and discuss entry modes (exports, use of representatives, licensing and franchising, joint ventures, direct investments). The choice usually depends on:

- Company goals

- Company available resources

- Company's necessary and available competencies

- Importance and risks involved in the country to be entered

- Characteristics of the company's product

- How much control the company/entrepreneur wants to have over the business, which in turn depends on the personal characteristics of the manager/entrepreneur, past experiences, and risk of the business.

The following table summarizes the pros and cons of each mode, according to the above issues:

Table 3. Pros and Cons of different entry modes.

\begin{tabular}{lll}
\hline \multicolumn{1}{c}{ Type of entry } & \multicolumn{1}{c}{ Advantages } & \multicolumn{1}{c}{ Disadvantages } \\
\hline Exports & $\begin{array}{l}\text { Speed of entry, lowest risk, lowest } \\
\text { investments (if available capacity) }\end{array}$ & $\begin{array}{l}\text { Lowest control, low local knowledge, liability of outsidership, } \\
\text { higher transportation costs, trade barriers }\end{array}$ \\
Licensing and franchising & $\begin{array}{l}\text { High speed of entry, with low cost, } \\
\text { and low risk }\end{array}$ & $\begin{array}{l}\text { Less control of the business (compared to FDI), licensee may } \\
\text { become a competitor, legal and regulatory environment (IP and } \\
\text { contract law) }\end{array}$ \\
Strategic alliances or JVs & $\begin{array}{l}\text { Shared costs and investments, } \\
\text { shared risks, seen as local }\end{array}$ & $\begin{array}{l}\text { Higher cost than previous options, possible integration or } \\
\text { cultural problems, possible legal problems in 50/50 partnerships }\end{array}$ \\
Direct investments & Maximum control of operations & Highest cost of investments, higher risks \\
\hline
\end{tabular}


In the case of BSH, although it continued to use exporting as its entry mode in the foreign market, there was a small increase in the company's commitment to certain markets, as described in the Uppsala theory (Johansson \& Vahlne, 1977; 1990). The instructor should use the case to lead the students through understanding the theory.

BSH initially entered the French market through a trading company in France, having later eliminated that intermediary and hired an exclusive sales agent to negotiate directly with distributors. However, it is true to say that this is one of the few instances in which the concepts proposed by the Uppsala theory (Johansson \& Vahlne, 1977; 1990) can be found in BSH's internationalization path. No increase in the firm's level of commitment was identified in connection with the other markets explored by BSH, nor was psychic distance noted as the main driving force in the firm's decisions to enter new markets - these target locations were selected because of the opportunities arisen from network relationships.

- How was the process of market selection at BSH? Did anyone influence the firm's expansion? Can you think of other possible ways of selecting new markets? Why do you think Andréa opted for one process instead of the other?

Two associations, namely ABIHPEC and ApexBrasil, deserve special attention in this process. Together, they created Beautycare Brazil, an industry-specific project of which BSH is a member and which aims to provide training and coaching to Brazilian companies that seek international markets' entry or expansion. It was how Andréa built her network relationships and made the necessary contacts to enter new markets. As a matter of fact, when we analyze BSH's internationalization process, we see that networks were essential not only in the choice of the target markets, but also in the financial and operational viability of its expansion. The project also finances the participation of member companies (such as BSH) in all the related events, which, according to Andréa, would not be possible otherwise.

Developed by Johanson and Mattson (1988), the network theory argues that markets behave as networks of interdependent companies. There would be a division of labor, with each company being responsible for an activity, which generates dependence and the need for coordination (Johanson \& Mattson, 1988). Several authors use the network theory as a basis to analyze the process of internationalization of firms, including Johansson and Vahlne, who have updated their Uppsala model in 2009 and 2013 to add it to the original model.

Also, the partnership with the Nazih Group, which began after BSH took part in the Cosmoprof fair in Dubai, shows an attempt to overcome two types of difficulties faced by the internationalization process into markets about which the firm has no previous knowledge and which are very complex: the 'liability of outsidership' (an expression that highlights the intricacies of entering a new market due to the difficulty in establishing relationships, in becoming a member of the network) and especially the 'liability of foreignness' (which entails difficulties regarding specific characteristics of being a foreigner in the host country) (Johansson \& Vahlne, 2009). Furthermore, building trust and commitment in relationships in the target market is another essential element considered by Johanson and Vahlne (2009) for the internationalization of firms.

In addition to helping the firm in this entry process, the Nazih Group has recently deepened its relationship with BSH aiming to extend their partnership in territories other than just the Middle East.

However, not all companies select the markets they will enter the same way BSH did. This is a difficult choice for a company that seeks to internationalize, and the instructor should discuss other possible ways with students.

Choice of markets can be: (a) Fortuitous, due to opportunities that emerge unexpectedly; (b) Based on intuitive criteria (psychic distance concept); (c) Based on objective and planned criteria, such as on market size and potential.

- How does the founder Andréa make her decisions? What can we say about her decision logic?

Seeking to fully understand the internationalization process of INVs, which includes the perspective of both the firm and the individuals involved, Andersson (2011) associates born globals to the logic of effectuation introduced by Sarasvathy (2001) as opposed to the logic of causation. These refer to two different decisionmaking approaches that are relevant in the analysis of firms' internationalization, given the importance of understanding the entrepreneurial behavior and skills to fully understand the internationalization 
process-an issue that was overlooked in previous theoretical discussions.

According to Sarasvathy (2001), decision making under the causation approach follows this order: a final goal is set, the means to achieve that goal are listed, then these means are limited based on environmental factors, and, finally, a criterion is used to select the best way to achieve that goal. Using the effectuation logic, on the other hand, Sarasvathy (2001) argues that entrepreneurs start the decision-making process based on three means: their personal characteristics, their knowledge, and their social cycle, i.e., their network. Then they determine the potential effects from using these means, and finally, select the best possible effect to work towards the initial aspiration goal. Therefore, while the logic of causation depends on the effect, or the ultimate goal, the logic of effectuation relies on the agent, or the means.

The touch point between Sarasvathy's (2001) theory and Andersson's (2011) association to international entrepreneurship is precisely this dependence on the agent to achieve the desired effect. As previously mentioned, Oviatt and McDougall (2005) do not consider the entrepreneurs' individual characteristics in the internationalization process, especially their proactivity and ability to envisage opportunities that were not expected in a foreseeable future. However, it is noticeable that the internationalization process is highly influenced by the experience of the individuals involved.

The logic in Sarasvathy's (2001) theory is based on four principles. The first principle involves measuring how much loss would be affordable to achieve a given goal, always from a long-term perspective (instead of applying a profit maximization model). Next, emphasis is placed on strategic alliances that could be built with stakeholders to reduce uncertainties (rather than focusing on a competitive analysis). The third principle involves the ability to leverage surprises that could arise (rather than just using pre-existing knowledge as a resource). Finally, attention is given to the controllable aspects of a future that is not predictable, and does not need to be, given that some aspects are controllable (rather than focusing on what is predictable in the future).

Thus, according to the effectuation logic, the internationalization process begins with the set of means of the effectuator (the entrepreneur), who arrives at a set of possible effects using his imagination and considering the affordable losses and risks. These results are affected not only by the characteristics of the decision maker, but also by the environment itself and by the surprises it brings. Accordingly, by making alliances with strategic partners and using the logic of controlling what is predictable, the effectuator achieves his aspirational goals. Thus, Sarasvathy's (2001) framework integrates the four perspectives: the economy, the industry, the firm, and the individual entrepreneur.

In an analysis of works such as Andersson's (2011), and noticing the intersection between the theory of international entrepreneurship and effectual reasoning, Sarasvathy et al. (2014) resume their theory by reorganizing the principles and adding a fifth element referred to by the authors as the "pilot-in-the-plane". This principle represents the individual's mission as an airplane pilot to build and command the future rather than just following trends.

Regarding Andréa's behavior, we can say the effectuation logic prevails. When Andréa started her business, the 'dream' of the firm's founder was to own a firm that could expand internationally. Her experience in the United States and in France, the fact that she worked in multinationals in the same industry and her first entrepreneurial failure in the domestic market may have been the factors that awakened this desire. In any case, it was by perceiving the reputation of Brazilian hair products in the French market that Andréa realized the potential of the sector and decided to start her company. Thus, the foregoing answers two of the questions proposed by Sarasvathy (2001): "who am I?" and "what do I know?".

The third question brought up by Sarasvathy (2001) - "who do I know?" - was even more important in the case of BSH, given the importance of network relationships in its internationalization process and choice of target markets. The selection of target markets for international expansion did not include defining the sequence of markets that should be prospected initially, opposing the psychic distance argument discussed in the Uppsala theory (Johanson \& Vahlne, 1977). In fact, the selection of these markets was largely influenced by the network relationships in the firm's international expansion process, since BSH entered countries promoted by ABIHPEC, which ensured access to international contacts in addition to information on foreign markets. 
It should also be noted that BSH displayed a 'chameleon' behavior (Matta \& Mello, 2014), having responded to surprises and uncertainties in the markets it entered using the effectuation logic. In spite of the diversity found in the markets, the firm was able to remain competitive by adapting its product formulas and packaging, or even by re-designing the product to a particular channel, as its network relationships were developed and the need to change products to stay competitive was perceived. Two examples illustrate this adaptability. The first involves X-Liso, which was created with the purpose of being sold to professionals in the beauty segment; however, since the use was simpler and the product was cheaper, Andréa targeted this product to a new type of channel - drugstores and beauty supply stores - and took advantage of its lower cost to penetrate countries where the economic situation was less favorable. Moreover, we can mention the case of the firm's entry into the Middle East, where, according to instructions set out by the Nazih Group, the product label had to be adapted to enter the market.

\section{Closure}

After reviewing BSH's internationalization process, we may conclude that it was born as an international firm. The attitude of exploring the foreign market very quickly, which is typical of companies considered 'born globals' (Rennie, 1993), is closely related to the entrepreneurial profile of Andréa Vieira, who follows the logic of effectuation (Sarasvathy, 2001), and behaves as a typical pilot-in-the-plane (Sarasvathy, Kumar, York, \& Bhagavatula, 2014).

Having "the world as a consumer market", as Andréa herself champions, was a choice based on two factors: her previous personal and professional experience, and her personal profile.

After all that has been discussed, would you enter the Brazilian market if you were Andréa? Why? What should be considered in making this decision (pros and cons of entering)?

As we saw, according to theory, BSH can succeed abroad without any presence domestically; however, there is a credibility aspect to this question due to the company's name.
The instructor should stimulate the debate among students, as there is no right answer for this question. A suggestion could be to divide the class into two groups: the ones in favor of entering the Brazilian market, and the ones against it; another idea would be to elect one representative of each position to debate and the class could vote on a verdict, like in a case court. Both of these suggestions would give the session a different dynamic, which could be interesting as it approaches the end and students sometimes start to get tired and lose attention. It depends on how much time the instructor has left.

The instructor can keep track of the arguments and organize the discussion by registering the students' comments in a 'pros and cons' table in the board, as shown in Table 4 below:

Table 4. Pros and cons of entering the Brazilian market.

\begin{tabular}{|c|c|}
\hline Pros & Cons \\
\hline Marketing (name) & Complexity of business will increase \\
\hline $\begin{array}{l}\text { Partnership with } \\
\text { Nazih Group }\end{array}$ & $\begin{array}{l}\text { Andréa's previous bad experiences in } \\
\text { the domestic market }\end{array}$ \\
\hline Market size & $\begin{array}{l}\text { Difficulties of domestic markets - } \\
\text { distribution, bureaucracy, to name a } \\
\text { few }\end{array}$ \\
\hline $\begin{array}{l}\text { Reputation of global } \\
\text { brand }\end{array}$ & Strong competitors well stablished \\
\hline Quality of products & $\begin{array}{l}\text { The advantage of "made in" effect } \\
\text { can disappear: one more in the crowd }\end{array}$ \\
\hline $\begin{array}{l}\text { Andréa's personal } \\
\text { characteristics }\end{array}$ & \\
\hline
\end{tabular}

Usually, students conclude that the company should consider investing in Brazil for marketing purposes despite the adversities of the Brazilian market and Andréa's bad previous experience.

Other aspects contribute to the argument of investing in the domestic market, namely (a) the intention of its largest partner, Nazih Group, to co-invest, (b) the size of the market (4th CT\&F market in the world and 3rd for hair products), (c) the quality of the products, already tested internationally, (d) the fact of being present in over 20 countries, which gives the brand a global image that can be leveraged domestically, and (e) Andréa's entrepreneurial and effectual management style, which enables her to adapt and try to find a market blank spot to fill. 


\section{REFERENCES}

Andersson, S. (2011). International entrepreneurship, born globals and the theory of effectuation. Journal of Small Business and Enterprise Development, 18(3), 627-643. https://dx.doi.org/10.1108/14626001111155745

Autio, E. (2005). Creative tension: The significance of Ben Oviatt's and Patricia McDougall's article 'toward a theory of international new ventures'. Journal of International Business Studies, 36(1), 9-19. https://dx.doi. org/10.1057/palgrave.jibs. 8400117

Chetty, S. K., \& Agndal, H. (2007). Social capital and its influence on changes in internationalization mode among small and medium-sized enterprises. Journal of International Marketing, 15(1), 1-29. https://doi.org/10.1509/ jimk.15.1.001

Chetty, S. K., \& Stangl, L. M. (2010) Internationalization and innovation in a network relationship context. European Journal of Marketing, 44(11/12), 17251743. https://doi.org/10.1108/03090561011079855

Coviello, N. E., McDougall, P. P., \& Oviatt, B. M. (2011). The emergence, advance and future of international entrepreneurship research - an introduction to the special forum. Journal of Business Venturing, 26(6), 625-631. https:// doi.org/10.1016/j.jbusvent.2011.07.002

Eisenhardt, K. M. (1989) Building theories from case study research. The Academy of Management Review, 14(4), 532-550. https://doi.org/10.2307/258557

Gabrielson, M., \& Kirpalani, V. H. M. (2004). Born globals: How to reach new business space rapidly. International Business Review, 13(5), 555-571. https://doi.org/10.1016/j.ibusrev.2004.03.005

Galkina, T., \& Chetty, S. (2012, September) Effectuation and the revisited uppsala model: Networking of internationalizing SMEs. Proceedings of the McGill International Entrepreneurship Conference, Pavia, Italy, 15.

Johanson, J., \& Mattson, L.-G. (1988). Internationalization in industrial systems - a network approach. In N Hood \& J Vahlne (Eds.), Strategies in global competition, (pp. 303-321). New York: Croom Helm.

Johanson, J., \& Vahlne, J.-E. (1977). The internationalization process of the firm - a model of knowledge development and increasing foreign market commitments. Journal of International Business Studies 8(1), 23-32. https://doi.org/10.1057/palgrave.jibs.8490676

Johanson, J., \& Vahlne, J.(1990). Themechanism of internationalization. International Marketing Review, 7(4). https://doi.org/10.1108/02651339010137414

Johanson, J., \& Vahlne, J.-E. (2009). The uppsala internationalization process model revisited: From liability of foreignness to liability of outsidership. Journal of International Business Studies, 40(9), 1411-1431. https://doi. org/10.1057/jibs.2009.24
Jones, M. V., Coviello, N., \& Tang, Y. K. (2011). International entrepreneurship research (1989-2009): A domain ontology and thematic analysis. Journal of Business Venturing, 26(6), 632-659. https://doi.org/10.1016/j. jbusvent.2011.04.001

Matta, J. R. N., \& Mello, R. D. C. (2014). A internacionalização de uma empresa brasileira de software de segurança à luz de teorias de rede e effectuation. Internext, 9(3), 83-100. http://dx.doi.org/10.18568/1980-4865.9378-94

Oparaocha, G. O. (2015). SMEs and international entrepreneurship: An institutional network perspective. International Business Review, 24(5), 861-873. https://doi.org/10.1016/j.ibusrev.2015.03.007

Oviatt, B. M., \& McDougall, P. P. (2005). Toward a theory of international new ventures. Journal of International Business Studies, 36(1), 29-41. https:// doi.org/10.1057/palgrave.jibs. 8400128

Rennie, M. W. (1993, Autumn). Born global. The McKinsey Quarterly, (4), 45-52. Retrieved from https://go.gale.com/ps/anonymous?id=GALE\%7CA15424561\&sid=googleScholar\&v=2.1\&it=r\&linkaccess $=$ abs $\&$ issn $=00475394 \& p=$ AONE $\&$ sw $=w$

Sarasvathy, S. D. (2001). Causation and effectuation: Toward a theoretical shift from economic inevitability to entrepreneurial contingency. The Academy of Management Review, 26(2), 243-263. https://doi.org/10.2307/259121

Sarasvathy, S., Kumar, K., York, J. G., \& Bhagavatula, S. (2014). An effectual approach to international entrepreneurship: Overlaps, challenges, and provocative possibilities. Entrepreneurship Theory and Practice, 38(1), 71-93. https://doi.org/10.1111/etap.12088

Schweizer, R. (2013). SMEs and networks: Overcoming the liability of outsidership. Journal of International Entrepreneurship, 11(1), 80-103. https://dx.doi. org/10.1007/s10843-012-0097-2

Vahlne, J.-E., \& Johanson, J. (2013). The uppsala model on evolution of the multinational business enterprise - from internalization to coordination of networks. International Marketing Review, 30(3), 189-210. https:// doi.org/10.1108/02651331311321963

Vahlne, J. \& Johanson, J. (2017). From internationalization to evolution: The uppsala model at 40 years. Journal of International Business Studies, 48(9), 1087-1102. https://doi.org/10.1057/s41267-017-0107-7

\section{RECOMMENDED READINGS (TO EXPLORE THE COUNTRY OF ORIGIN ASPECT OF THE CASE)}

Magnusson, P., \& Westjohn, S. A. (2011). Is there a country-of-origin theory? In S.C. Jain \& D. A. Griffith (Eds.), Handbook of research in international marketing (pp. 292-316). Northampton, MA: Edward Elgar Publishing.

Magnusson, P., Westjohn, S. A., \& Sirianni, N. J. (2019). Beyond country image favorability: How brand positioning via country personality stereotypes enhances brand evaluations. Journal of International Business Studies, 50(3), 318-338. https://doi.org/10.1057/s41267-018-0175-3

Sharma, P. (2011a). Country of origin effects in developed and emerging markets: Exploring the contrasting roles of materialism and value consciousness. Journal of International Business Studies, 42(2), 285-306. https://doi. org/10.1057/jibs.2010.16
Sharma, P. (2011b). Demystifying cultural differences in country-of-origin effects: Exploring the moderating roles of product type, consumption context, and involvement. Journal of International Consumer Marketing, 23(5), 344-364. https://doi.org/10.1080/08961530.2011.602952

Suh, T., \& Smith, K. H. (2008). Attitude toward globalization and country-of-origin evaluations: Toward a dynamic theory. Journal of Global Marketing, 21(2), 127-139. https://doi.org/10.1080/08911760802135202

Verlegh, P. W. J., \& Steenkamp, J.-B. E. M. (1999). A review and meta-analysis of country-of-origin research. Journal of Economic Psychology, 20(5), 521-546. https://doi.org/10.1016/S0167-4870(99)00023-9 


\section{Authors}

\section{Lucyana Felicia}

Rua Pascoal Lemme, no 355, Ilha do Fundão, 21941-901, Rio de Janeiro, RJ, Brazil.

E-mail address: lucyanafelicia@gmail.com

(ㄴ https://orcid.org/0000-0003-1217-4879

\section{Clarice Secches Kogut*}

Rua Pascoal Lemme, no 355, Ilha do Fundão, 21941-901, Rio de Janeiro, RJ, Brazil.

E-mail address: clarice.kogut@coppead.ufrj.br

난 https://orcid.org/0000-0002-4760-654X

\section{Renato Dourado Cotta de Mello}

Rua Pascoal Lemme, nº 355, Ilha do Fundão, 21941-901, Rio de Janeiro, RJ, Brazil.

E-mail address: renato@coppead.ufrj.br

ㄴ https://orcid.org/0000-0003-2345-1202

* Corresponding Author

\section{Funding}

The authors report that there is no financial support for the research in this article.

\section{Conflict of Interest}

The authors have stated that there is no conflict of interest.

\section{Copyrights}

RAC owns the copyright to this content.

\section{Authors' Contributions}

$1^{\text {st }}$ author: Largest contribution related to the original data collection. She also contributed to the conception of the work, analysis and interpretation of data, writing and critical review, final approval and overall responsibility.

$2^{\text {nd }}$ author: Greater contribution regarding the design of the work, development and transformation of data suitable for the case for teaching. She also contributed to the acquisition and analysis of data, writing and critical review, final approval and overall responsibility.

$3^{\text {rd }}$ author: Greater contribution regarding the text elaboration, critical review and final approval. He also contributed to the work design, acquisition, analysis and interpretation of data and overall responsibility.

\section{Plagiarism Check}

The RAC maintains the practice of submitting all documents approved for publication to the plagiarism check, using specific tools, e.g.: iThenticate.

\section{Peer Review Method}

This content was evaluated using the double-blind peer review process. The disclosure of the reviewers' information on the first page is made only after concluding the evaluation process, and with the voluntary consent of the respective reviewers. 